\title{
The Influence of Transformational Leadership, Work Environment, and Religiosity toward Employee Loyalty of IAIN Salatiga
}

\author{
Endah Nur Fitriyani \\ Institut Agama Islam Negeri Salatiga \\ endahfitriyani@iainsalatiga.ac.id
}

Masuk: 16 Maret 2018; Diterima: 7 Juni 2018; Terbit: 25 Juni 2018

\begin{abstract}
This study aims at determining the effect of transformational leadership, work environment and religiosity toward employee loyalty. The type of research used is survey research with quantitative approach. Population and sample in this research are civil servant employees of IAIN Salatiga amounting to 54 people. A method of data collection in this study is using questionnaires. The results from multiple regression analysis obtained results for transformational leadership variable does not have a significant impact on employee loyalty; work environment variable has no significant effect on employee loyalty; religiosity variable has a positive influence on employee loyalty; and transformational leadership, work environment, and religiosity simultaneously have a significant effect on employee loyalty. The value of Adjusted $R$ Square is 0.922 which means that $92.2 \%$ variance of loyalty can be explained by the variance of the three independent variables: transformational leadership, work environment, and religiosity.
\end{abstract}

Keywords: transformational leadership; work environment; religiosity; employee loyalty

\begin{abstract}
Abstrak
Penelitian ini bertujuan untuk mengetahui pengaruh kepemimpinan transformasional, lingkungan kerja dan religiusitas terhadap loyalitas karyawan. Jenis penelitian yang digunakan adalah penelitian survey dengan pendekatan kuantitatif. Populasi dan sampel dalam penelitian ini adalah karyawan PNS IAIN Salatiga yang berjumlah 54 orang. Metode pengumpulan data dalam penelitian ini menggunakan kuesioner. Dari hasil analisis regresi berganda diperoleh hasil untuk variabel kepemimpinan transformasional tidak berpengauh secara signifikan terhadap loyalitas karyawan; variabel lingkungan kerja tidak berpengaruh secara signifikan terhadap loyalitas karyawan; variabel religiusitas memiliki pengaruh positif terhadap loyalitas karyawan; dan kepemimpinan transformasional, lingkungan kerja dan religiusitas secara simultan berpengaruh signifikan terhadap loyalitas karyawan. Besarnya nilai Adjusted R Square adalah 0,922 yang berarti bahwa $92,2 \%$ varians loyalitas dapat dijelaskan varians dari ketiga variabel independen: kepemimpinan transformasional, lingkungan kerja, dan religiusitas.
\end{abstract}

Kata Kunci: kepemimpinan transformasionall lingkungan kerja; religiusitas; loyalitas karyawan 


\section{INTRODUCTION}

There are some key successes to make a successful company, one of them is employee loyalty. Companies need employees who have a high loyalty because with a high loyalty, employees can work in accordance with the standards given by the company and they can improve the quality of work. Loyalty affects the convenience of employees to work in a company and it is important to have them in it.

Loyalty is a positive attitude of employees to the company or organization where he works. According to Nitisemito (2004), loyalty is a mental attitude of employees who are shown to the existence of the company so that employees will remain in the company, even though the company is developing or not. Siagian (in Wellyanto \& Halim, 2017) defines loyalty as a tendency for employees not to move to other companies. Loyal employees are highly valued by the company because the company desperately needs employees who are loyal to the company's sustainability in determining the company's future (Pradana \& Nugraheni, 2015). Loyalty indicators according to Saydam (2004) are as follows:

1. Obedience or compliance

2. Responsible

3. Devotion

4. Honesty

However, increasing loyalty is not an easy thing, loyalty is a determination and a willingness to obey, implement and practice something that is adhered to with full of awareness and responsibility. Employee loyalty does not appear on its own but it requires a good leader and good management to create employee loyalty. One of the most important elements in efforts to increase loyalty is a leader who is able to influence his subordinates and actively involve his subordinates in achieving that goal through appropriate leadership styles (Kharis, Hakam \& Ruhana, 2015).

Leadership is a factor which has a central role in an organization. Many factors affect the success of an organization in achieving its objectives, but it will not work without the presence of a leader who can direct and drive the organization toward the achievement of organizational goals. To realize its success, a leader requires subordinates who will help the achievement of organizational goals (Ridito \& Kasmirudin, 2016).

In the global competition era, many organizations shifted the transactional leadership style paradigm to transformational leadership as a way of achieving strategy and goals where transformational leadership styles fit a dynamic organizational environment (Ismail, in Putra, 2015). Transformational leaders can communicate vision and goals clearly so that they can influence and motivate subordinates to improve their performance.

The transformational leadership style is the type of leader who inspires his followers to put aside their personal interests and possess extraordinary influence abilities. The main aspect of transformational leadership is the emphasis on directing followers, therefore Yukl (in Kharis, Hakam \& Ruhana, 2015) suggests some guidelines for transformational leaders:

1. Stating the vision and mission clearly

2. Explain how the vision can be trusted

3. Acting optimistically to achieve the vision 
4. Demonstrate belief in employee

5. Use dramatic and symbolic actions to emphasize important values

6. Lead by example

7. Giving authority to the employee to achieve the vision

Transformational leaders tend to communicate the vision and goals of the organization clearer so that subordinates can identify and tend to have a strong influence on the employee, motivate their employee and stimulate creativity to perform better in order to achieve organizational goals (Putra, 2015). Transformational leaders are able to make organizational changes because this form of leadership develops a higher level of intrinsic motivation, trust, commitment, and loyalty rather than transactional leadership (Robins \& Judge, 2008). Good leadership is needed to develop employees and create employee loyalty to improve productivity (Ariyani, Aini \& Tjahjono, 2016).

One important element in the effort to improve employee productivity is a leader who is able to provide clear direction for the organization and employees are willing to execute these directives for the achievement of expected goals and create job satisfaction (Pambudi, Mukzam \& Nurtjahjono, 2016). The more aspects of the job that suits the individual's desire, the higher of perceived satisfaction level they will get. Employees with high job satisfaction tend to exert more effort in carrying out their duties and will generate loyalty to their work.

The results of Amri, Suharnomo, and Rahardja (2016) research, showed that the transformational leadership style has a positive and significant effect on employee loyalty where the employees of PT. Kimia Farma Plant Manufacturing Semarang feels close to leaders who have good communication and closeness to their employees so that they can receive messages delivered by their leaders. Tuna, Ghazzawi, Tuna, and Çatir (2011) conducted research on hospital industry in Turkey and concluded that transformational leadership enhances employee commitment and loyalty to the organization.

Employee loyalty can also be created when management is able to create a comfortable, safe and enjoyable work environment for employees to carry out their work. Employees will pay great attention to their work environment, both in terms of personal convenience and ease of doing their job (Robbins \& Judge, 2008). According to Sedarmayanti (2009), the work environment is the whole tools and materials encountered, the surrounding environment where a person works, methods of work, as well as the arrangement of work either as individuals or groups. A pleasant working environment can make employees feel at home in completing their work and able to achieve an optimal result. Conversely, if the condition of the work environment is not adequate, it will cause a negative impact in decreasing the level of employee performance productivity.

The working environment is divided into the physical and nonphysical work environment. Physical work environment means all physical circumstances that exist around the workplace where it can affect the work of employees either directly or indirectly such as space motion, color, air circulation, lighting, cleanliness, and security. While non-physical work environment means all the circumstances that occur related to the working relationship, either with superiors or with fellow co-workers, or with subordinates (Sedarmayanti, 2009).

Maineldi, Hendriani, and Daulay (2014) research shows that the work environment has a positive effect on employee loyalty which means that with better work environment 
will increase employee loyalty of PT Jatim Jaya Perkasa Kebun Banjar Balam Indragiri Hulu. In line with Maineldi et al. the results of Purba (2017) study shows that work environment has a significant effect on loyalty where the higher work environment will affect the increase of employee loyalty.

Employee loyalty is also closely related to obedience where loyalty will increase along with closeness with the Creator. Employees who have a good level of religiosity will be reflected by high motivation and dedication of work because they understand exactly what is done in the task not only expect salary or honorarium, but there is a higher expectation of rewards that are far greater which is from Allah SWT. Religion as a universal feature of social human life in the sense that all societies have a way of thinking and behavioral patterns that meet to be called "religion" consisting of the types of symbols, images, beliefs, and specific values which human beings interpret their existence which contains ritual components (Ishomuddin, 2002).

From this religious term then emerged what is called religiosity. Diversity or religiosity is manifested in all sides of human life. Religious activity not only happens when a person performs a ritual (worship) but also performs other activities that are driven by final powers. Not only is it related to the visible and visible activity of the eye, but also an activity that does not appear and occurs in one's heart. Hence the diversity of a person will encompass a variety of dimensions. The notion of religiosity based on the dimensions encountered by Glock and Stark (in Ancok \& Suroso, 2005) is how far the knowledge, how strong the beliefs, how diligent the implementation of worship and how deep religious appreciation a person holds.

In the hadith, the Messenger of Allah also said:

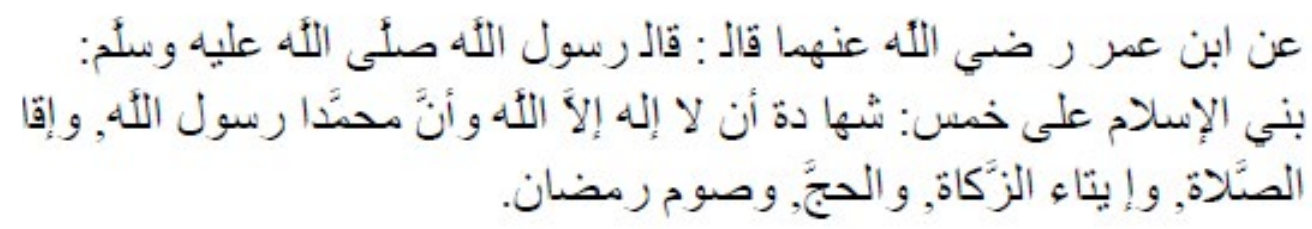

From Ibn Umar (may Allah be pleased with him) he said: Allah's Messenger (may peace be upon him) said: The religion of Islam is built on five elements there are testifying that there is no god but Allah and Muhammad is a servant of Allah's messenger, performing prayers, paying Zakat, doing Hajj and fasting in Ramadan. (HR. Bukhari and Muslim)

Religiosity in Islam includes the five things that are belief, worship, deed, morals, and knowledge. A religious Muslim will have a central feature of a strong belief. Belief concerns belief in Allah, Angels, Messanger of Allah, and human relationships with God. The dimension of worship concerning the implementation of prayer, zakat, fasting, pilgrimage, reciting the Qur'an, prayer, zikr and so on. The deed is concerning the implementation of human relationships with fellow beings, for example: helping others, defending the weak and working.

Religiosity influences as a motivation in encouraging individuals to perform an activity, because deeds done with a background of religious belief are judged to have elements of purity and obedience. This linkage will have an effect on someone to do 
something. While religion as a value of ethics because in doing something one's actions will be bound to the provision between which is allowed and which should not according to religious teachings he embraced (Jalaluddin, 2015).

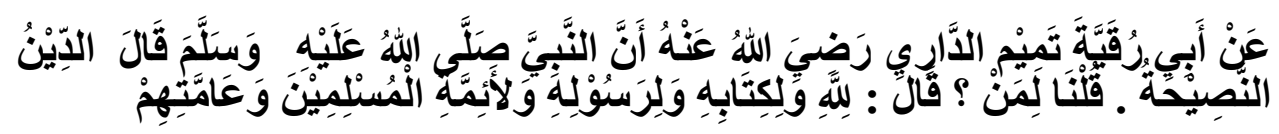

From Abu Ruqoyah Tamim Ad Daari radhiallahuanhu, the Messenger of Allah (peace and blessings of Allaah be upon him) said: Religion is advice, we say: To whom? he said: To Allah, His Holy Book, His Apostle and to the leader of the Muslims and their people (HR. Bukhari and Muslim).

The result from Najiyah (2017) research shows the values of religiosity affect the Work Agency loyalty at PT. Takaful General Surabaya Branch. Employees, who have a good level of religiosity and have a high quality of work life, will increase loyalty in work that is working beyond the established work standards, work voluntarily and not easily complain against the challenges faced.

Based on some previous research indicates that leadership style has a significant effect on employee loyalty, work environment influence to employee loyalty and religiosity influence to employee loyalty. The difference in this research is to know the influence of transformational leadership style, work environment and religiosity on employee's loyalty to the religious institution. The hypotheses proposed in this study are as follows:

H1 : Transformational leadership positively affects employee loyalty.

H2 : Work environment positively affects employee loyalty.

H3 : Religiosity has a positive effect on employee loyalty.

H4 : Transformational leadership, work environment and religiosity simultaneously affect employee loyalty.

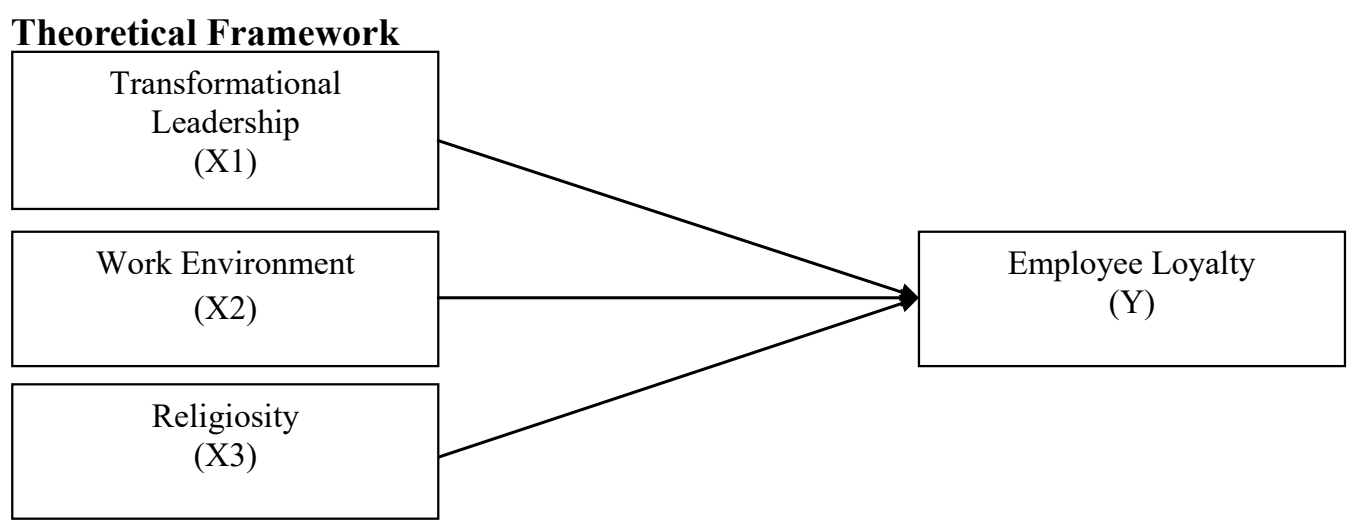

Picture 1. Theoretical Framework 


\section{The Definition of Operational Variables}

Loyalty is a mental attitude of employees who are shown to the existence of the company so that employees will remain in the company, even though the company is advanced or backward (Nitisemito, 2004)

1. Obedience or compliance

2. Responsible

3. Devotion

4. Honesty

Transformational leadership is the type of leader who inspires his followers to put aside their personal interests and possess extraordinary influence abilities (Yukl in Kharis et al., 2015)

1. Stating the vision and mission are clear and interesting

2. Explain how the vision can be trusted

3. Acting optimistically to achieve the vision

4. Demonstrate belief in followers

5. Use dramatic and symbolic actions to emphasize important values

6. Lead by example

7. Giving authority to followers to achieve the vision

Work environment: The working environment is divided into the physical and non-physical work environment. Physical work environment that is all physical circumstances that exist around the workplace where it can affect the work of employees either directly or indirectly such as space motion, color, air circulation, lighting, cleanliness and security, while non-physical work environment that is all the circumstances that occur related to the working relationship, either with superiors or with fellow co-workers, or with subordinates (Sedarmayanti, 2009).

Religiosity: how far the knowledge, how strong the beliefs, how diligent the implementation of worship and how deep religious appreciation of a person embraced (Glock \& Stark in Ancok \& Suroso, 2005)

1. belief,

2. worship,

3. deed,

4. morals,

5. knowledge.

\section{METHOD}

The research design chosen in this study is a quantitative cross-sectional design in which data are collected at the same time (or in a short time frame). The type of data in this study is primary data, the authors distribute and collect direct questionnaires from respondents who are employees of civil servants at State Institute for Islamic Studies (IAIN) Salatiga. The population in this research is employees of the State Institute for Islamic Studies Salatiga with the status of civil servants as many as 54 employees. The sampling method used is the saturated sampling method because of the small population so that all members of the population are the respondents in the study. The measurement tool used in this study is the measurement of ordinal data using Likert Scale with five levels of answers from score 1 for very disagree (STS) to score 5 for very agree (SS). 


\section{RESULT AND DISCUSSION}

From 54 questionnaires distributed, 43 returned questionnaires, 1 questionnaire returned but could not be processed. Based on reliability testing all the variables used obtained reliable results for all question items with Cronbach's Alpha values of more than 0.70 means that if Cronbach's Alpha value is more than 0.70 then the questions to measure observed variables are "reliable" (Ghozali, 2013).

Validity test is used to measure the validity or validity of a questionnaire. A questionnaire is said to be valid if the question on the questionnaire is able to reveal something that will be measured by the questionnaire (Ghozali, 2013). Validity test in this research is done by using Spearman Rank correlation test because data source correlated is ordinal data. Based on the results of validity test that has been done on 28 indicators contained in the three variables indicate a significance value of less than 0.05 so that all indicators are valid.

Normality test is done by testing the residual normality using Kolmogorov-Smirnov non-parametric statistical test. The results of multicollinearity test for each independent variable it can be concluded that no independent variable has a tolerance value of less than 0.10 which means there is no correlation between independent variables and based on the calculation of Variance Inflation Factor (VIF) for each independent variable that has no value more than 10 , so it can be concluded that the independent variables used in the regression model of this study are free from multicollinearity.

Heteroscedasticity test aims to test whether in the regression model the variance inequality of one residual observation to another observation (Ghozali, 2013). A good regression model is homoscedasticity. In this study, the heteroscedasticity testing is done using Glejser test. Based on test results of significant value of any independent variables above 0.05 , it can be concluded that the regression model in this study did not occur heteroscedasticity.

The autocorrelation test aims to test whether in the linear regression model there is a correlation between the disturbance error in period $t$ and the disturbance error in period $\mathrm{t}-1$ (previous) (Ghozali, 2013). This study uses the Durbin-Watson (DW Test) to test whether autocorrelation occurs on the basis of decision making (hypothesis) as follows: $\mathrm{H} 0$ : if the value $\mathrm{d}$ lies between du and (4-du), there is no autocorrelation whereas H1: if value $\mathrm{d}$ is smaller than $\mathrm{dl}$ or more than $(4-\mathrm{dl})$, then there is autocorrelation. Durbin Watson test results show d value of 2.154 which means more than the upper limit of (du) 1.659 and lies between $4-1.659(4-\mathrm{du})$, it can be concluded that $\mathrm{H} 0$ is accepted which means that there is no autocorrelation in the regression model.

Regression analysis is performed to look at the dependence variables on one or more independent variables, in order to estimate and/or predict the average population or the mean value of the dependent variable based on the value of the known independent variable (Gujarati in Ghozali, 2013). The accuracy of the regression function in estimating the actual value can be measured from the coefficient of determination, the F statistic, and the statistical value $t$. The statistical calculation is statistically significant when the value of the statistical test is in the critical area (the area where $\mathrm{H} 0$ is rejected) and is not significant if the test value is in the region where HO is received (Ghozali, 2013). 
Table 1. Coefficient of Determination

\begin{tabular}{cccc}
\hline $\mathrm{R}$ & $\mathrm{R}$ Square & Adjusted R Square & Std. Error of the Estimate \\
\hline 0,963 & 0,928 & 0,922 & 0,972 \\
\hline
\end{tabular}

The value of Adjusted $R$ Square is 0.922 which means that $92.2 \%$ variance of loyalty can be explained by the variance of the three independent variables: transformational leadership, work environment, and religiosity; while the remaining $7.8 \%$ is explained by the reasons beyond the research model.

Table 2. Simultaneous Significance Test

\begin{tabular}{cccc}
\hline Model & df & F & Sig. \\
\hline Regression & 3 & & \\
Residual & 38 & 162,099 & 0,000 \\
Total & 41 & & \\
\hline
\end{tabular}

Based on table 2 above, the value of $\mathrm{F}$ arithmetic is 162.099 with probability 0.000 which means that the probability value is much less than 0.05 , then the regression model can be used to predict loyalty or in other words that transformational leadership, work environment, and religiosity simultaneously influence toward employee loyalty.

Based on table 2 above, the value of $F$ arithmetic is 162.099 with probability 0.000 which means that the probability value is much less than 0.05 , then the regression model can be used to predict loyalty or in other words that transformational leadership, work environment, and religiosity simultaneously influence toward employee loyalty.

Table 3. Individual Parameter Significance Test

\begin{tabular}{lcc}
\hline \multicolumn{1}{c}{ Model } & $\mathrm{t}$ & Sig. \\
\hline Transformational Leadership & 1,083 & 0,286 \\
Work environment & 0,467 & 0,643 \\
Religiosity & 14,931 & 0,000 \\
\hline
\end{tabular}

Of the three independent variables included in the regression model, transformational leadership variables and work environment variables are not significant. This can be seen from the probability significance for the transformational leadership variable of 0.286 and the significance value for the working environment variable of 0.643 and both well above 0.05 . The variable religiosity significance value of 0.000 or below 0.05 . Based on testing the significance of individual parameters with statistical test $t$ it can be concluded that employee loyalty variable is influenced by variable religiosity with the mathematical equation as follows:

Employee loyalty $=4,424+0,128$ transformational leadership $+0,070$ work environment $+1,107$ religiosity which means that the variable religiosity has a positive and significant effect on employee loyalty. The coefficient of regression of religiosity of 1.107 indicates that every increase of employee's religiosity will increase employee loyalty of 1.107 .

\section{The influence of transformational leadership toward employee loyalty}

The results of data analysis performed for the first hypothesis testing (H1) showed 
the result that the regression coefficient of the influence of transformational leadership variable toward employee loyalty obtained significance value of 0.286 or above 0.05 and $t$ value of 1.083 less than the value of $t$ table 2.024. This shows that the first hypothesis (H1) which states that transformational leadership significant effect on employee loyalty is rejected. It can be concluded that transformational leadership has no effect on IAIN Salatiga employee loyalty.

The results of this study contradict from Amri, et al. (2016), and Tuna et al. (2011). In the first hypothesis, the coefficient value is marked positive indicating that the higher the transformational leadership style then the loyalty will increase. Thus, the style of transformational leadership needs to be improved because employees with a leader who is able to protect and treat subordinates well will increase employee loyalty where with high levels of employee loyalty then the employee will take positive action on his work.

\section{The influence of the work environment toward employee loyalty}

The results of data analysis performed for the second hypothesis testing (H2) showed the result that the regression coefficient of the influence of work environment variables on employee loyalty obtained a significance value of 0.286 or above 0.05 and the value of $t$ arithmetic of 0.467 smaller than the value of $t$ table of 2.024. This shows that the second hypothesis (H2) which states that the work environment has a significant effect toward employee loyalty is rejected. It can be concluded that the work environment does not affect the loyalty of IAIN Salatiga employees. The results of this study contradict with the result from the Maineldi et al. (2014) and Purba (2017) research.

In the second hypothesis the coefficient value is marked positive indicating that the better the work environment of the employee, the loyalty will increase. Thus, the working environment both physically and non physically need to be improved because with better working environment conditions then employees will feel comfortable and able to work conducive that will further increase employee loyalty.

\section{The influence of religiosity toward employee loyalty}

The result of data analysis conducted for the third hypothesis testing (H3) shows the result that the regression coefficient influence the religiosity variable toward employee loyalty obtained by significance value 0.000 or below 0,05 and $t$ value is equal to 14,931 or more than $t$ value table 2,024. This shows that the third hypothesis $(\mathrm{H} 3)$ which states that religiosity has a significant effect on employee loyalty is accepted. So it can be concluded that the variable religiosity has a positive and significant effect on employee loyalty. This shows that the better the level of employee religiosity, the greater the employee loyalty.

The results of this study are in line with the results of research Najiyah (2017) which shows that employees who have a good level of religiosity and have high quality of work life, will increase loyalty in work that is working beyond the established work standards, work voluntarily and not easily complain against the challenges faced.

\section{The influence of transformational leadership, work environment, and religiosity toward employee loyalty}

Fourth hypothesis (H4) the influence of transformational leadership, work environment and religiosity simultaneously affect the loyalty of IAIN Salatiga employees. In the fourth hypothesis, the coefficient value is marked positive indicating that the higher 
the transformational leadership, the work environment and the better the religiosity of an employee will increase employee loyalty to the work. The value of Adjusted R Square is 0.922 which means that $92.2 \%$ variance of loyalty can be explained by the variance of the three independent variables: transformational leadership, work environment, and religiosity; while the remaining $7.8 \%$ is explained by the reasons beyond the research model.

\section{CONCLUSION}

Based on the formulation of research problems proposed, then the results of data analysis has been done and the discussion has been raised, can be drawn conclusions of this study that the first hypothesis (H1) which states transformational leadership have a positive effect on employee performance, based on the data analysis results obtained significance value of 0.286 or in more than 0.05 so that the first hypothesis (H1) rejected. In the first hypothesis, the coefficient value is marked positive indicating that the higher the transformational leadership style then the loyalty will increase.

The second hypothesis (H2) which states the work environment has a positive effect on employee performance, based on the data analysis results obtained significance value 0.643 or in more than 0.05 so that the second hypothesis (H2) rejected. The working environment both physical and non-physical need to be improved because when employees feel comfortable with the environment and able to work conducive that will further increase employee loyalty.

The third hypothesis (H3) which express religiosity have a positive effect on employee performance, based on the data analysis results obtained significance value 0.000 or below 0.05 so that the third hypothesis (H3) accepted. In the third hypothesis, the coefficient value is marked positive indicating that the better the religiosity of an employee will increase employee loyalty to the work. The fourth hypothesis (H4) which states transformational leadership, work environment, and religiosity together have a positive effect on employee loyalty, based on the data analysis results obtained significance value 0.000 or below 0.05 so that the fourth hypothesis (H4) accepted.

\section{REFERENCES}

Amri, R. F., Suharnomo, \& Rahardja, E. (2016). Pengaruh Kepemimpinan Transformasional dan Kepuasan Kerja Terhadap Loyalitas Yang Berdampak Pada Kinerja Karyawan di Perusahaan (Studi Pada PT. Kimia Farma Plant Manufacturing Semarang). Jurnal Bisnis STRATEGI. 25 (1).

Ancok, D., \& Suroso, F. N. (2005) Psikologi Islami. Yogyakarta: Pustaka Pelajar.

Ariyani, R. I., Aini, Q., \& Tjahjono, H. K. (2016). Pengaruh Gaya Kepemimpinan dan Loyalitas Karyawan Terhadap Kinerja Karyawan di Rumah Sakit Islam Hidayatullah Yogyakarta. Jurnal Medicoeticoilegal dan Manajemen Rumah Sakit. 5 (2).

Ghozali, I. (2013). Aplikasi Analisis Multivariate dengan Program IBM SPSS 21. Semarang: Badan Penerbit Universitas Diponegoro.

Ishomuddin. (2002). Pengantar Sosiologi Agama. Jakarta: Ghalia Indonesia.

Jalaluddin. (2015). Psikologi Agama Edisi Revisi. Jakarta: PT.Raja Grafindo Persada.

Kharis, I., Hakam, M. S., \& Ruhana, I. (2015). Pengaruh Gaya Kepemimpinan Transformasional Terhadap Kinerja Karyawan dengan Motivasi Kerja sebagai Variabel Intervening (Studi Pada Karyawan Bank Jatim Cabang Malang). Jurnal Administrasi Bisnis (JAB). 3 (1). 
Maineldi, A., Hendriani, S., \& Daulay, I. N. (2014). Pengaruh kompensasi dan lingkungan kerja terhadap loyalitas karyawan pada PT. Jatim Jaya Perkasa Kebun Banjar Balam Indragiri Hulu. JOM FEKON. 1 (2).

Najiyah, F. (2017). Pengaruh Nilai-Nilai Religiusitas Terhadap Loyalitas Kerja Agency Pada PT. Takaful Umum Cabang Surabaya. OECONOMICUS Journal Of Economics. 1 (2).

Nitisemito, A.S. (2004). Manajemen Personalia (Manajemen Sumber Daya Manusia). Jakarta : Ghalia Indonesia.

Pambudi, D. S., Mukzam, D., \& Nurtjahjono, G. E. (2016). Pengaruh Gaya Kepemimpinan Transformasional Terhadap Kinerja Karyawan Melalui Kepuasan Kerja Karyawan Sebagai Variabel Mediasi (Studi Pada Karyawan PT Telkom Indonesia Witel Jatim Selatan Malang). Jurnal Administrasi Bisnis (JAB). 39 (1).

Pradana, R., \& Nugraheni, R. (2015). Analisis Pengaruh Kepuasan Kerja, Loyalitas Kerja, dan Lingkungan Kerja Non Fisik Terhadap Kinerja Karyawan (Studi Pada Bank Indonesia Kota Semarang). Diponegoro Journal of Management. 4 (4).

Purba, B. K. (2017). Pengaruh Kompensasi Dan Lingkungan Kerja Terhadap Loyalitas Karyawan (Studi Kasus PT. Capella Dinamik Nusantara Cab. Kandis). JOM FISIP. 4 (1).

Putra, W. H. (2015). Pengaruh Work-Family Conflict, Gaya KepemimpinanTransformasional, Dan Kompleksitas Tugas Terhadap Job Satisfaction Auditor. Akuntabilitas. 8 (3).

Ridito, R., \& Kasmiruddin. (2016). Pengaruh Kepemimpinan Transformasional Terhadap Loyalitas Kerja Karyawan Pada PT. Jasa Raharja Cabang Pekanbaru. JOM FISIP. 3 (1).

Robbins, S., \& Judge, T. A. (2008). Perilaku Organisasi Edisi Ke-12. Jakarta: Salemba Empat

Saydam, G. (2004). Manajemen Sumber Daya Manusia (Human Resources Management): Suatu Pendekatan Mikro (Dalam Tanya Jawab). Jakarta: Djambatan.

Sedarmayanti. (2009). Tata Kerja dan Produktivitas Kerja. Bandung: CV. Mandar Maju

Tuna, M., Ghazzawi, I., Tuna, A.A., \& Çatir, O. (2011). Transformational Leadership and Organizational Commitment: The Case of Turkey's Hospitality Industry S.A.M. Advanced Management Journal. 76 (3).

Wellyanto, S. C., \& Halim, G. A. (2017). Analisa Pengaruh Gaya Kepemimpinan Terhadap Loyalitas Karyawan Hotel X Bali. Jurnal Hospitality dan Manajemen Jasa. 5 (2). 